the Ben-a conclusion in keeping with the result obtained at low level.

It is concluded from the observations that high winds reduce the transparency of the air. In Part I. this conclusion is indicated, and the observations of $\mathrm{I} 890$ confirm it. It is pointed out that whenever the wind was high, the air was unduly thick for the number of particles and the humidity. This is thought to be due to high winds carrying large particles, and mixing the lower stratum of in pure air with the purer upper air. The inequalities in the density of the different parts of the air produced by imperfect mixing will also reduce its transparency.

The Alford observations for I 890 show that the air was occasionally purer and the maximum a little higher in that year than on the previous visit. Whenever the wind blew from the south, it brought polluted air to this station, as it came from inhabited areas; and when the wind was northerly the air was pure. The number of particles was as low as 127 per c.c. with a north-west wind, while it was as high as 6800 per c.c. with a south wind.

An ascent of Callievar was made in 1890 also. On the first visit the air was clear, and the Cairngorms and Lochnagar were clearly seen. The number of particles was 262 per c.c., and rose in the afternoon to 475 per c.c. ; but on the second visit the air was thick, and only a faint outline of the Cairngorms was occasionally seen, while Lochnagar was quite invisible. The number of particles was $7 \mathrm{IO}$, and rose in the afternoon to 1575 per c.c.

The air on this occasion was very irregularly hazed, not being equally transparent in all directions. One mass of air darkened the view to the west, passed over the hill-top and darkened the view to the east. Before this impure mass of air arrived at the hill-top the number of particles was 7 IO, while it was passing the number rose to 1575 , and after it had gone east the number fell to ro5o per c.c. During these observations the humidity remained constant. The variations in the transparency were therefore due to variations in the amount of dust.

The condition of the air during the exceptionally warm February of 1890 was tested at Garelochhead on the 27 th of the month. Previous to that date the weather had been very warm, temperatures of $50^{\circ}$ and $60^{\circ}$ having been frequently recorded in our area, and even $64^{\circ}$ was observed in more places than one. The result of the tests showed the air to be remarkably full of dust. During the visit to this station in the end of January 1889 , the maximum number of particles observed was 2360 , and that was the only occasion on which it was over 1000 ; whilst on the first day of the second visit the smallest number observed was 7250 , and other readings gave nearly 10,000 . During this warm period the air was always impure, and had nuch the same appearance as it had on the 27 th. The cause of this great amount of impurity was the presence of an anticyclone lying over Europe, giving rise to southerly winds over our area. The local winds were, however, very light and mixed, and there was no general circulation of the air; the dust impurities therefore accumulated, and, as the figures show, became very great. On the 28 th, the day after the air was tested, a depression appeared off the north of our islands, and the isobars were closing in and westerly winds were beginning to blow. With this change the dust began to fall, and was as low as 1750 per c.c. on the 28th. On March $I$ and 2 the isobars closed in still further, the winds freshened, and the dust fell to 5 I per c.c., or $\frac{l}{200}$ of what it was on February 27. During the $3 \mathrm{rd}, 4 \mathrm{th}$, and 5 th, the wind remained in the north-west, and the amount of dust was very small.

Certain relations between isobars and dust are pointed out. With regular isobars for westerly and northerly winds the air is pure, and the closer the isobars the purer is the air ; whilst isobars for southerly or easterly winds, even though close, do not indicate pure air. From these facts it is shown that an estimate of the amount of dust on any day can be made from an examination of the weather charts made on and previous to the day selected.

The relation between the amount of dust and the temperature is discussed, with the view of finding whether the observations made in 1890 confirm the conclusion arrived at from the previous records. That conclusion was that a great amount of dust increases the day temperature and checks the fall of temperature at night. The records of temperature and radiation made at Kingairloch in 1890 are of no value, owing to the weather being always under the influence of cyclones, so that there was an absence of clear skies, and the temperatures were regulated by what the winds brought, and were but little influenced by local conditions. But, as already stated, the dust at this station was exceedingly low in 1890 , and the temperature was also exceptionally low.

The Alford observations, however, are not open to the same defect, as the weather was suitable for the purpose. These observations point to the same conclusion as that arrived at in 1889 . The highest maximum temperatures were recorded on days of high dust, and the lowest minimum when the dust was at a minimum.

The observations made at Garelochhead also support the same conclusion. Towards the end of February the amount of dust was great, and from the meteorological report it will be seen that the temperature was above the mean, and was frequently very high. Again, when the westerly winds swept away the great impurity, they brought with them a high mean temperature. But after the winds ceased to blow, the pure air brought to our area by them seems to have allowed radiation to act freely, as the air then rapidly cooled, and the temperature became exceedingly low, as much as from 8 to I I degrees below the mean in some stations in Scotland. The Ben Nevis observations show that during this exceptionally cold period the air was remarkably free from dust.

\section{JOHN COUCH ADAMS}

$\mathrm{I}^{\mathrm{T}}$ is with deep regret that we record the death of Prof. Adams, who will always hold an eminent place in the history of astronomical science. As he is included in the list of our "Scientific Worthies," we have already given an account of his career (vol. xxxiv. p. 565). It is only necessary for us now, therefore-as in the case of Sir George Airy - to note some of the leading facts of his life and work.

He was born at Lidcot, near Launceston, in Cornwall, on June 5, 1819. He received his early education at the village school and at Devonport, where he gave evidence of his remarkable faculty for mathematical and astronomical study. In October 1839 , he entered at St. John's College, Cambridge; and in 1843 he graduated as Senior Wrangler and first Smith's Prizeman, becoming shortly afterwards a Fellow and tutor of his College.

Both before and after taking his degree he was fascinated by a problem which was at that time profoundly interesting astronomers-the irregularities shown by the planet Uranus in its motion. Its orbit differed from the elliptic path which an undisturbed planet would have pursued; and as the deviations could not be explained by the influence of the other known planets, it was supposed that there must be a more remote planet which had not then been observed. To the search for this unknown planet Adams devoted all the energies of his mathematical genius, and everyone knows the brilliant success with which his labours were crowned. His solution was communicated to Prof. Challis in September I845, and to the Astronomer-Royal in the following month. We need only refer to the facts that similar work was done in 1846 by Leverrier; that the French astronomer's results, unlike those of the English investi-

NO. I I 6 I, VOL. 45] 
gator, were at once made known; and that on September 23,1846 , the planet Neptune was found by Dr. Galle, of Berlin, on the basis of Leverrier's elements. Adams and Leverrier rank as joint discoverers, and, as such, they received on February II, I848, the gold medal of the Royal Astronomical Society. Some members of Adams's college, in order to mark their sense of the importance of his achievement, raised a fund, which the University accepted, for the founding of a prize, to be called "The Adams Prize," to be awarded every two years to the author of the best essay on some subject of pure mathematics, astronomy, or other branch of natural philosophy. In 185 I he was elected President of the Royal Astronomical Society.

As he did not take orders, his Fellowship at St. John's expired in 1852 , but he continued to reside in the College until 1853 , when he was elected to Pembroke. In 1858 he was appointed Professor of Mathematics at the University of St. Andrews, but he held this office only during a single session. $\mathrm{He}$ became the Lowndean Professor of Astronomy and Geometry, at Cambridge, in 1859 , in succession to the late Prof. Peacock, and retained this position during the remainder of his life.

Meanwhile, he had been carrying on many important investigations; and, until ill-health disabled him, his labours were never seriously interrupted. Foremost among his later achievements were the results of his researches on the moon and on the theory of the November meteors. In 1866 the Royal Astronomical Society awarded him its gold medal for his lunar researches. $\mathrm{He}$ had succeeded Prof. Challis as Director of the Cambridge Observatory in 1861 , and in 1884 he served as one of the delegates for Great Britain at the International Meridian Conference at Washington.

For about a year and a half before his death, Prof. Adams was too ill to do as much work as he had been accustomed to do, and during the last ten weeks he was confined to bed. He died on the morning of January $2 \mathrm{r}$.

He was a Fellow of the Royal Society, and of the leading foreign scientific bodies; and honorary degrees were conferred upon him by his own University and by Oxford The post of Astronomer-Royal was offered to him by the First Lord of the Admiralty in I88I, on Sir George Airy's retirement, but declined by him on the ground of age.

\section{WALTER HOOD FITCH.}

THIS talented botanical artist, whose name appears in almost every illustrated work of importance on botany or horticulture that was published in this country during the half-century from 1835 to 1885 , expired at his residence at Kew on the I4th inst., after several years' indisposition, in which mental and physical decay were combined. The deceased was 75 years of age, and his whole life from early youth had been devoted to botanical drawing and painting; and his reputation was so high and so world-wide that it is unnecessary to say much on this point. Nevertheless, some particulars of the work of a man who accomplished so much and so well may be interesting to many persons who only know his work. Of Scotch birth, he was apprenticed, while still very young, to the designing department in a manufactory of fancy cotton goods at Paisley. Here his natural aptitude for drawing developed so rapidly and to such a degree as to indicate that he possessed talents of no ordinary kind, and his name soon became known outside of the factory. By some means he came under the notice of a friend of the late Sir William Hooker, and he, knowing that the latter was in need of a draughtsman, strongly recommended him to try the youth's capabilities. Sir William Hooker, at that time Regius Professor of Botany at Glasgow, acted on this suggestion, and the result was so satisfactory that he negotiated the cancel of Fitch's indentures, took him into his sole employ, and trained him for the kind of work he wished hin to execute. We have not ascertained the exact date of this event, but it must have been as early as the year 1832 , for already in I834 he was a contributor to the Botanical Magazine, and he continued his connection with this long-lived periodical down to 1878 , having during this period drawn and lithographed some 3000 of the plates. At first his initials did not appear regularly on the plates, but, on reference to the volume for 18.37 , it may be seen that it was practically all his, and that he had already become an efficient botanical draughtsman. The same year (1 837) the first volume of Hooker's "Icones Plantarum" was published, and although F'itch's name does not appear, we have other evidence that he was the artist. In short, he not only illustratec all the numerous works of his first patron, but also those of his son, now Sir Joseph Hooker, as well as those of numerous other public and private persons. The fertility of his pencil was equalled by its facility, grace, vigo ur, and boldness ; and his colouring was usually rich, and full, and truthful. It is true that most of his work does not exhibit the finish and minute detail characteristic of the masterpieces of the productions of the few other botanical artists with which comparisons could be made. In I 841, Sir William Hooker was appointed Director of the Royal Gardens, Kew, Fitch accompanying him, and residing there until his death. At Kew he found full scope for his powers, and notable amongst the numerous productions of his best days are the magnificent elephant folio plates representing various stages of the development of the Victoria regia as cultivated at Kew and Syon House ; the plates of Sir William Hooker's numerous works on ferns; of Sir Joseph F ooker's " Botany of Sir James Ross's Antarctic Voyage"; and his "Illustrations of Himalayan Plants and Himalayan Rhododendrons"; of Howard's "Quinologia": of Bateman's "Odontoglossum"; of Welwitch's "West African Plants"; of Speke and Grant's "Plants of the Upper Nile" ; and of Seemann's "Botany of the Voyage of the Herald." Examples of his later work are to be found in Elwes's "Lilies," and the botany of Salv in and Godman's "Biologia Centrali-Americana," the latter the last important work he accomplished. As might be imagined from the amount of work he did, Fitch wielded the pencil with remarkable rapidity and freedom; and one could not but admire the way in which he stood up and, free handed, guided his pencil over the stone without any preliminary drawing. Botanical drawing, however, is not a very lucrative profession, and therefore not likely to attract persons of great attainments; but when Fitch became incapacitated through failing health, his merits were so far recognized as to gain him a Civil List pension, on the recommendation of the Earl of Beaconsfield, of $£$ roo a year.

\section{NOTES.}

MARCH $I 7$ is the date fixed for the Bakerian Lecture of the Royal Society, and Prof. James Thomson is to be invited to deliver it. The Croonian Lecture is to be cielivered on March 24 by Prof. Angelo Mosso, of Turin, the subject being "The Temperature of the Brain."

AT the Council Meeting of the Royal society on the 2Ist inst., no fewer than ten deaths were announced, seven of the deceased having been Fellows of the Royal Society, and three Foreign Members. Taking into account that the average number of deaths for the whole year is fifteen, such a list for a single month is quite extraordinary. NO. I I 6I, VOL. 45] 